\title{
'Candidatus Phytoplasma fragariae', a novel phytoplasma taxon discovered in yellows diseased strawberry, Fragaria $\times$ ananassa
}

\author{
Deividas Valiunas, ${ }^{1,2}$ Juozas Staniulis ${ }^{1}$ and Robert E. Davis ${ }^{2}$ \\ ${ }^{1}$ Laboratory of Phytoviruses, Institute of Botany, Zaliuju ezeru 49, Vilnius LT-08406, Lithuania \\ 2USDA-ARS, Molecular Plant Pathology Laboratory, Beltsville, MD 20705, USA
}

Correspondence

Robert E. Davis

davisr@ba.ars.usda.gov

\begin{abstract}
Symptoms of general stunting and yellowing of leaves were observed in diseased cultivated strawberry (Fragaria $\times$ ananassa Duchesne) in Lithuania. Analysis of 16S rRNA gene sequences amplified by PCR indicated that the symptoms were associated with infection by a phytoplasma, designated strawberry yellows (StrawY) phytoplasma. Phylogenetic analysis of 16S rRNA gene sequences indicated that StrawY phytoplasma, 'Candidatus Phytoplasma australiense', 'Candidatus Phytoplasma asteris', stolbur phytoplasma and 'Candidatus Phytoplasma japonicum' shared a common ancestor, but were mutually distinct. Nucleotide sequence alignments of a $1 \cdot 3 \mathrm{~kb}$ 16S rRNA gene sequence fragment revealed that StrawY phytoplasma shared $97 \cdot 4 \%$ or less similarity with previously described 'Candidatus Phytoplasma' species. These results, in addition to natural host and geographical occurrence, support the recognition of StrawY phytoplasma as a representative of a novel taxon, 'Candidatus Phytoplasma fragariae'.
\end{abstract}

Phytoplasmas are wall-less, plant-pathogenic bacteria that are classified in the class Mollicutes. In diseased plants, phytoplasmas reside in the sieve elements of phloem tissue. Phloem-feeding insects, mainly leafhoppers, transmit phytoplasmas from plant to plant (Davis \& Lee, 2000). Fifteen phytoplasma groups (16Sr groups) and more than $40 \mathrm{sub}-$ groups have been delineated on the basis of results from RFLP analysis of 16S rRNA gene sequences (Lee et al., 1998; Marcone et al., 2000; Davis et al., 2001; Jomantiene et al., 2002a). Thus far, three 16Sr groups (16SrI, 16SrIII and $16 \mathrm{SrV}$ ) and eleven subgroups have been reported in Lithuania (Jomantiene et al., 2000, 2002a, b; Staniulis et al., 2000; Valiunas et al., 2000, 2001a, b, 2004; Urbanaviciene et al., 2005). Based on $16 \mathrm{~S}$ rRNA gene sequences, 20 'Candidatus Phytoplasma' species have been described (IRPCM, 2004; Schneider et al., 2005).

In this communication, we propose that a phytoplasma associated with a disease of strawberry be considered as a novel 'Ca. Phytoplasma' species. Symptoms of general stunting and yellowing of leaves were observed in diseased

Published online ahead of print on 30 September 2005 as DOI 10.1099/ijs.0.63935-0.

Abbreviation: STOL, stolbur phytoplasma group.

The GenBank/EMBL/DDBJ accession number for the 16S rRNA gene sequence of phytoplasma strain StrawY is DQ086423.

A supplementary table showing the unique regions in the $16 \mathrm{~S}$ rRNA gene sequence of 'Candidatus Phytoplasma fragariae' compared with other 'Candidatus Phytoplasma' species is available in IJSEM Online. cultivated garden strawberry (Fragaria $\times$ ananassa Duchesne) in Lithuania, suggesting possible infection by a phytoplasma. Evidence of an association of phytoplasma with the disease, termed strawberry yellows (StrawY), was obtained by the use of PCR primed by phytoplasma-specific oligonucleotides to amplify phytoplasma $16 \mathrm{~S}$ rRNA gene sequences. Results from comparative analysis of the $16 \mathrm{~S}$ rRNA gene sequences indicated that StrawY phytoplasma is taxonomically distinct from previously described ' $\mathrm{Ca}$. Phytoplasma' species.

Three separate samples of leaf tissue were collected from a naturally infected symptomatic strawberry plant growing at a farm in Kavarskas, Anyksciai region, Lithuania, in 2004. Nucleic acid for use as a template in PCR was extracted from each sample according to Jomantiene et al. (1998). The three nucleic acid samples were used in three separate PCRs in which two pairs of oligonucleotides were used to prime the amplification of rRNA gene sequences. P1/P7 (Deng \& Hiruki, 1991; Schneider et al., 1995) and R16F2n/R16R2 (Gundersen \& Lee, 1996) are oligonucleotide pairs that prime the amplification of sequences from phytoplasma rRNA operons as described previously (Lee et al., 1993). Products from nested PCR, primed by R16F2n/R16R2 according to Gundersen \& Lee (1996), were analysed by single enzyme digestion with AluI, MseI, KpnI, HaeIII, HhaI, HpaII, RsaI, HinfI and TaqI (MBI Fermentas) according to the manufacturer's instructions. The resulting RFLP patterns were compared with previously published data (Lee et al., 1998; Marcone et al., 2000). The 16S rRNA gene products from the three PCRs primed by $\mathrm{P} 1 / \mathrm{P} 7$ were cloned 
as described previously (Jomantiene et al., 1998) and the three cloned DNA fragments were sequenced by automated sequencing of both strands to achieve a minimum of $4 \times$ coverage per position. The nucleotide sequence determined in this study was deposited in GenBank. Other sequences used in the study were obtained from GenBank and their accession numbers are given in Figs 2 and 3. Maps of putative restriction sites were constructed by the use of the MapDraw program in the DNASTAR software package. For calculations of sequence similarities, sequences were aligned by using the ALIGN program in the same software package. For phylogenetic analysis, $16 \mathrm{~S}$ rRNA gene sequences from 20 'Ca. Phytoplasma' species, StrawY phytoplasma and Acholeplasma palmae were aligned using CLUSTAL_X, version 1.63b (Thompson et al., 1997). A phylogenetic tree was constructed by the neighbour-joining method and the tree was viewed by using TREEVIEWPPC (Page, 1996). A. palmae was selected as the outgroup to root the tree. Bootstrapping was performed 1000 times for estimation of stability and support for the clades.

Amplification of phytoplasmal 16S rRNA gene fragments in three separate PCRs primed by phytoplasma universal primer pairs indicated that the strawberry plant affected by strawberry yellows disease in Kavarskas, Lithuania, was infected by a phytoplasma, designated strain StrawY (data not shown). Results from comparative analysis of collective RFLP patterns of a $1 \cdot 2 \mathrm{~kb}$ segment of the $16 \mathrm{~S}$ rRNA gene sequence, corresponding to the DNA fragment amplified in PCR primed by R16F2n/R16R2, indicated that the StrawY phytoplasma was related to group 16SrI and 16SrXII phytoplasmas and 'Candidatus Phytoplasma japonicum', but was distinct from the these phytoplasmas (Figs 1 and 2). For example, StrawY phytoplasma was distinguishable from 'Ca. Phytoplasma japonicum' by the presence of MseI, RsaI, $K p n \mathrm{I}, E c o$ RI and AluI sites that were absent in the ' $\mathrm{Ca}$. Phytoplasma japonicum' 16S rRNA gene fragment. In addition, a HhaI site in the ' $\mathrm{Ca}$. Phytoplasma japonicum' $16 \mathrm{~S}$ rRNA gene sequence was absent in StrawY. The 16S rRNA gene sequence of StrawY phytoplasma was distinguished from that of the stolbur (STOL) phytoplasma (group 16SrXII) by the presence of MseI and HhaI sites that were absent in the STOL 16S rRNA gene sequence and by HaeIII, TaqI and MseI sites in STOL phytoplasma 16S rRNA gene sequences that were absent in StrawY. The 16S rRNA gene sequence of 'Candidatus Phytoplasma australiense' (group 16SrXII) lacked MseI, AluI and HhaI sites that were present in StrawY and had HaeIII and two MseI recognition sites that were absent in StrawY 16S rRNA gene sequences. StrawY 16S rRNA gene sequences differed from those of 'Candidatus Phytoplasma asteris' (group 16SrI) by the presence of three sites for MseI, one HindIII and one AluI site in StrawY and by the lack of a HaeIII site in ' $\mathrm{Ca}$. Phytoplasma asteris' that was present in StrawY. The 16S rRNA gene sequence of StrawY phytoplasma had one unique MseI restriction site that was absent in these other phytoplasmas. Thus, StrawY, 'Ca. Phytoplasma japonicum', STOL phytoplasma, ' $C a$. Phytoplasma australiense' and ' $\mathrm{Ca}$. Phytoplasma asteris'

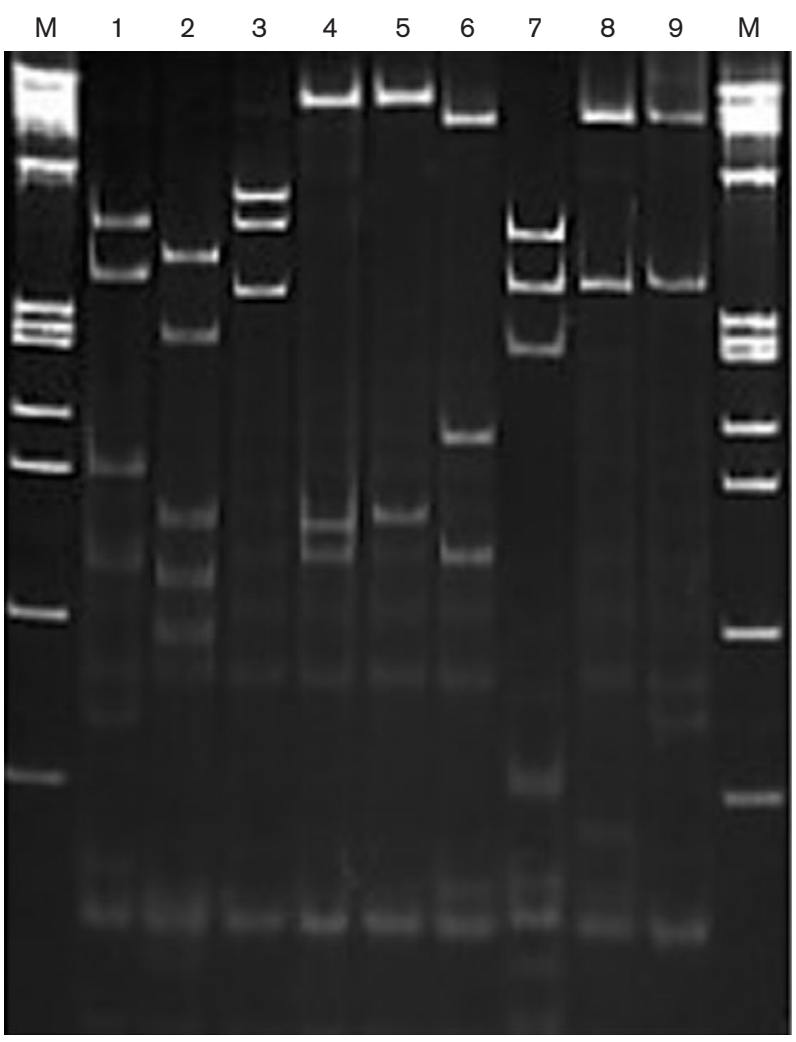

Fig. 1. RFLP analysis of $16 \mathrm{~S}$ rRNA gene sequences amplified in nested PCR primed by oligonucleotide pair R16F2n/R16R2 from 'Ca. Phytoplasma fragariae'. Lanes: 1, Alul; 2, Msel; 3, Kpnl; 4, Hhal; 5, Haell; 6, Hpall; 7, Rsal; 8, Hinfl; 9, Taql; M, Marker, a PhiX174 DNA/BsuRI (Haell) digest size standard with fragment sizes of $1353,1078,872,692,310,281,271$, 234, 194, 118 and $72 \mathrm{bp}$.

phytoplasmas could be distinguished from one another by RFLP analysis of $16 \mathrm{~S}$ rRNA gene sequences.

A phylogenetic tree was constructed based on 16S rRNA gene sequences from all previously described ' $\mathrm{Ca}$. Phytoplasma species', StrawY phytoplasma and A. palmae (Fig. 3). The branching order of the tree is in good agreement with that of previously published trees (IRPCM, 2004; Lee et al., 2004). The phylogenetic analysis indicated that StrawY phytoplasma (shown as the proposed species ' $\mathrm{Ca}$. Phytoplasma fragariae'), 'Ca. Phytoplasma japonicum', 'Ca. Phytoplasma australiense' and ' $\mathrm{Ca}$. Phytoplasma asteris' shared a common ancestor. 'Ca. Phytoplasma fragariae' formed a new, well-supported branch representing a distinct lineage.

The nucleotide sequences of three cloned DNA fragments were in agreement. Alignment of 1333-base segments of $16 \mathrm{~S}$ rRNA gene sequences indicated that StrawY phytoplasma contained nucleotide sequences previously reported as unique to phytoplasmas (Gundersen et al., 1994; IRPCM, 2004). In addition, the StrawY phytoplasma 16S rRNA gene sequence contained unique nucleotide sequences that 


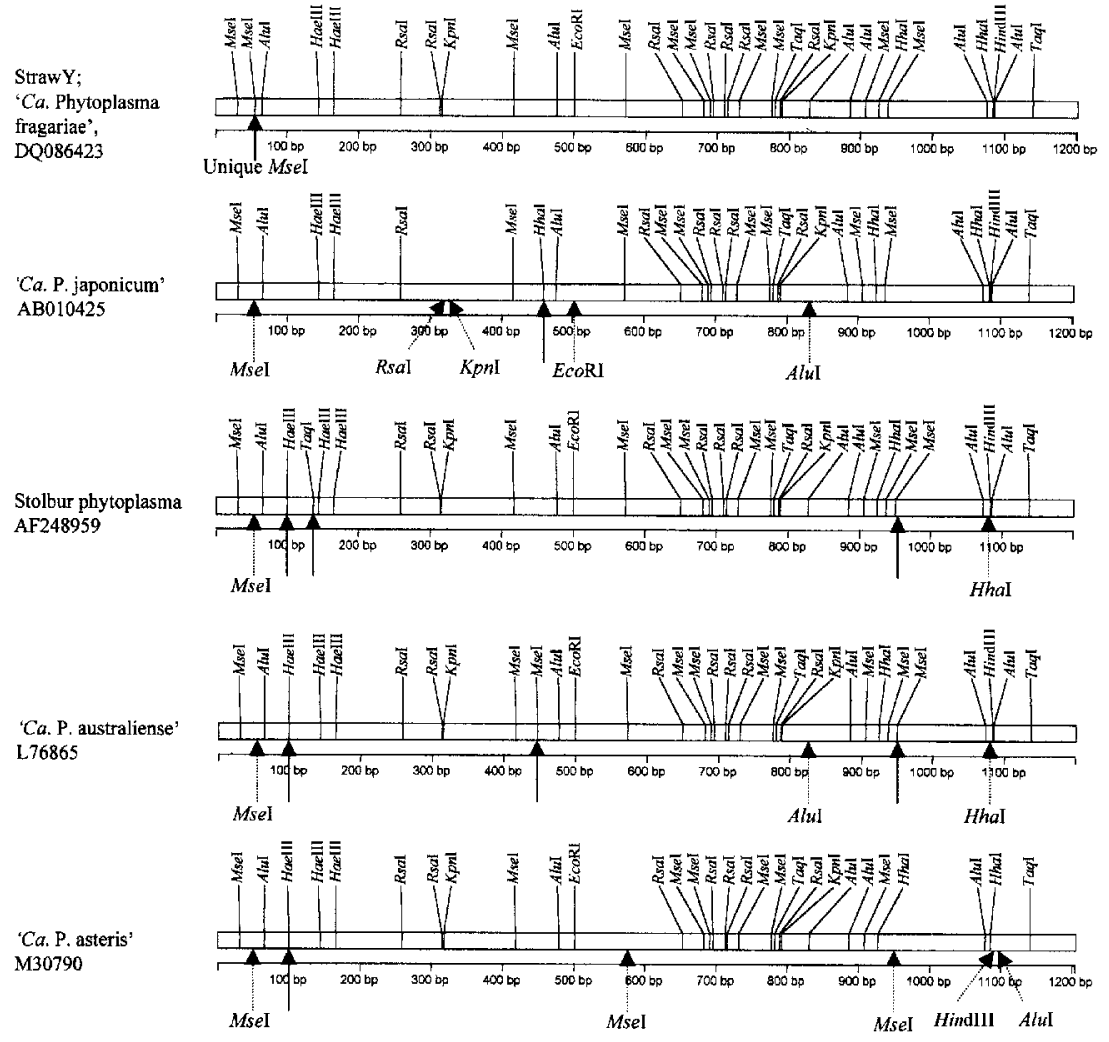

Fig. 2. Comparative analysis of putative restriction sites in 16S rRNA gene sequences corresponding to DNA amplified from 'Ca. Phytoplasma fragariae' phytoplasma and its closest known relatives in PCRs primed by oligonucleotide pair R16F2n/R16R2. Arrows indicate restriction sites that differentiate ' $\mathrm{Ca}$. Phytoplasma fragariae' from other phytoplasmas. Broken arrows indicate sites present in the 16S rRNA gene sequence of ' $\mathrm{Ca}$. Phytoplasma fragariae' and absent in other 16S rRNA gene sequences.

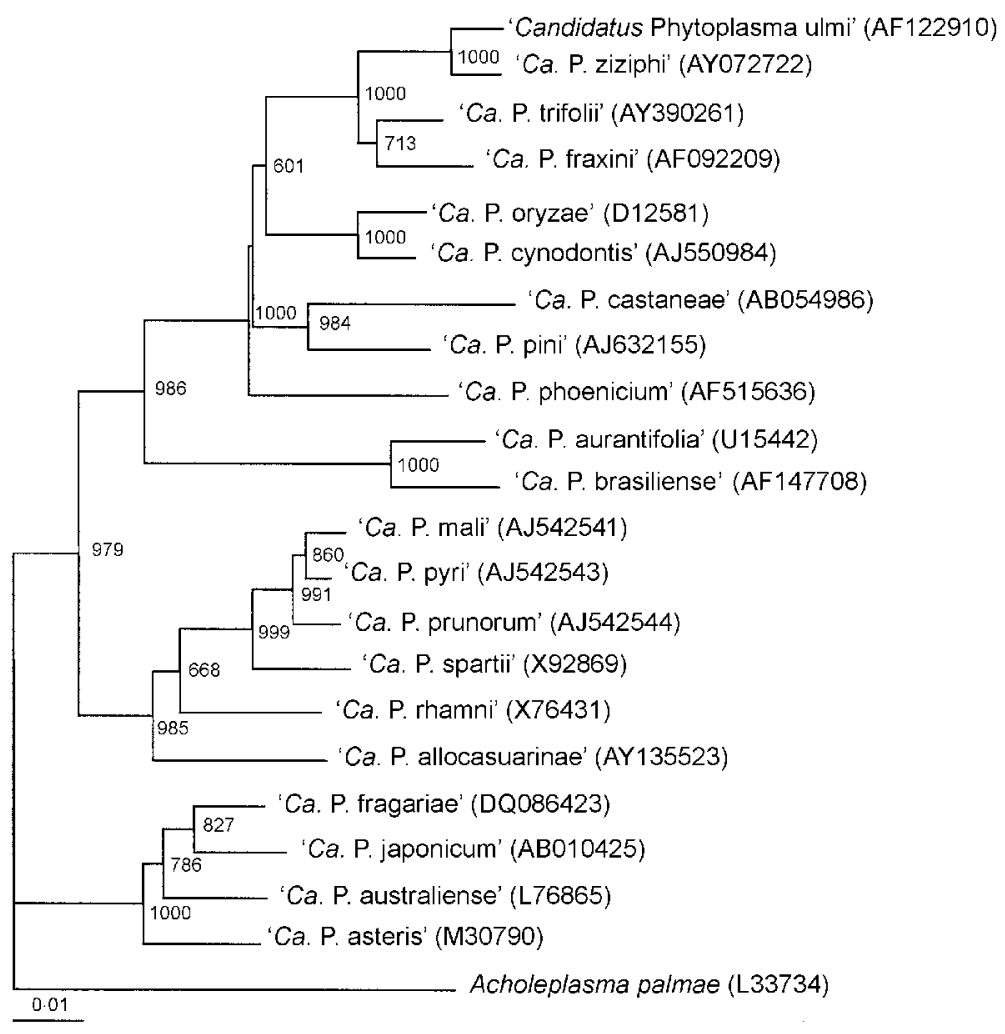

Fig. 3. Phylogenetic tree constructed by the neighbour-joining method of 16S rRNA gene sequences from previously described ' $\mathrm{Ca}$. Phytoplasma' species, 'Ca. Phytoplasma fragariae' and Acholeplasma palmae, employing A. palmae as the outgroup. Bar, 1 substitution in 100 nucleotides. Numbers on the nodes are bootstrap (confidence) values. 
distinguished it from all previously described ' $\mathrm{Ca}$. Phytoplasma' species. A table comparing the nucleotide sequences of unique regions in the 16S rRNA gene sequence of the StrawY phytoplasma is available as Supplementary Table S1 in IJSEM Online. Unique regions in the StrawY phytoplasma 16S rRNA gene fragment are ${ }_{482} 5^{\prime}$-GTGCAATGCTCAACGTTGTGAT-3' ${ }_{503},{ }_{899} 5^{\prime}$-AATTGCA-3' ${ }_{905}$ and ${ }_{1313} 5^{\prime}$-TGAGTAATCAAGAGGGAG- ${ }^{\prime}{ }_{1330}$, which differ in from one to eight, from one to six and from two to eleven base positions, respectively, from the corresponding regions in the $16 \mathrm{~S}$ rRNA gene sequences of previously described ' $\mathrm{Ca}$. Phytoplasma' species.

Sequence comparisons revealed that the StrawY phytoplasma $1.3 \mathrm{~kb} 16 \mathrm{~S}$ rRNA gene sequence segment shared no greater than $97 \cdot 4 \%$ nucleotide sequence similarity with any previously described 'Ca. Phytoplasma' species. According to recommendations by the International Research Program for Comparative Mycoplasmology, Phytoplasma/Spiroplasma Working Team - Phytoplasma Taxonomy Group (IRPCM, 2004), "a 'Ca. Phytoplasma' species description should refer to a single, unique $16 \mathrm{~S}$ rRNA gene sequence ( $>1200 \mathrm{bp}$ )" and "a strain can be recognized as a novel ' $\mathrm{Ca}$. Phytoplasma' species if its $16 \mathrm{~S}$ rRNA gene sequence has $<97.5 \%$ similarity to that of any previously described ' $\mathrm{Ca}$. Phytoplasma' species". Results from rRNA gene sequence analysis, in addition to the natural host and the geographical location, support the recognition of StrawY phytoplasma as a representative of a novel taxon. Thus, we propose that the StrawY phytoplasma be designated a member of a novel, distinct 'Candidatus' species, 'Candidatus Phytoplasma fragariae'.

\section{Description of 'Candidatus Phytoplasma fragariae'}

'Candidatus Phytoplasma fragariae' (frag'ar.i.ae. N.L. gen. n. fragariae of Fragaria, the scientific name of strawberry; epithet referring to the plant host).

Reference isolate is strain Straw $Y^{\mathrm{R}}$.

[(Mollicutes) NC; NA; O; NAS (GenBank accession number DQ086423), oligonucleotide sequences of unique regions of the 16S rRNA gene are 5'-GTGCAATGCTCAACGTTGTGAT-3', 5'-AATTGCA-3' and 5'-TGAGTAATCAAGAGGGAG-3'; P (Fragaria $\times$ ananassa, phloem); M]. Valiunas et al., this study.

\section{Acknowledgements}

We are grateful to Ellen L. Dally and Jonathan Shao for excellent technical assistance and Rasa Jomantiene for advice on amplification and cloning of DNA.

\section{References}

Davis, R. E. \& Lee, I.-M. (2000). Phytoplasma. In Encyclopedia of Microbiology, 2nd edn, pp. 640-646. Edited by J. Lederberg and others. New York: Academic Press.
Davis, R. E., Dally, E. L. \& Converse, R. H. (2001). Molecular identification of a phytoplasma associated with witches'-broom disease of black raspberry in Oregon and its classification in group 16SrIII. New subgroup Q. Plant Dis 85, 1121.

Deng, S. \& Hiruki, C. (1991). Amplification of $16 \mathrm{~S}$ rRNA genes from culturable and non-culturable mollicutes. J Microbiol Methods 14, 53-61.

Gundersen, D. E. \& Lee, I.-M. (1996). Ultrasensitive detection of phytoplasmas by nested-PCR assays using two universal primer pairs. Phytopathol Mediterr 35, 144-151.

Gundersen, D. E., Lee, I.-M., Rehner, S. A., Davis, R. E. \& Kingsbury, D. T. (1994). Phylogeny of mycoplasmalike organisms (phytoplasmas): a basis for their classification. J Bacteriol 176, 5244-5254.

IRPCM (2004). 'Candidatus Phytoplasma', a taxon for the wall-less, non-helical prokaryotes that colonize plant phloem and insects. Int J Syst Evol Microbiol 54, 1243-1255.

Jomantiene, R., Davis, R. E., Maas, J. \& Dally, E. L. (1998). Classification of new phytoplasmas associated with diseases of strawberry in Florida, based on analysis of 16S rRNA and ribosomal protein gene operon sequences. Int J Syst Bacteriol 48, 269-277.

Jomantiene, R., Davis, R. E., Antoniuk, L. \& Staniulis, J. (2000). First report of phytoplasmas in soybean, alfalfa, and Lupinus sp. in Lithuania. Plant Dis 84, 198.

Jomantiene, R., Davis, R. E., Valiunas, D. \& Alminaite, A. (2002a). New group 16SrIII lineages in Lithuania exhibit rRNA interoperon sequence heterogeneity. Eur J Plant Pathol 108, 507-517.

Jomantiene, R., Davis, R. E., Alminaite, A., Valiunas, D. \& Jasinskaite, R. (2002b). First report of oat (Avena sativa L.) as host of a phytoplasma belonging to group 16SrI, subgroup A. Plant Dis 86, 443.

Lee, I.-M., Hammond, R. W., Davis, R. E. \& Gundersen, D. E. (1993). Universal amplification and analysis of pathogen 16S rDNA for classification and identification of mycoplasmalike organisms. Phytopathology 83, 834-842.

Lee, I.-M., Gundersen-Rindal, D. E., Davis, R. E. \& Bartoszyk, I. M. (1998). Revised classification scheme of phytoplasmas based on RFLP analyses of $16 \mathrm{~S}$ rRNA and ribosomal protein gene sequences. Int J Syst Bacteriol 48, 1153-1169.

Lee, I.-M., Gundersen-Rindal, D. E., Davis, R. E., Bottner, K. D., Marcone, C. \& Seemüller, E. (2004). 'Candidatus Phytoplasma asteris', a novel phytoplasma taxon associated with aster yellows and related diseases. Int J Syst Evol Microbiol 54, 1037-1048.

Marcone, C., Lee, I.-M., Davis, R. E., Ragozzino, A. \& Seemüller, E. (2000). Classification of aster yellows-group phytoplasmas based on combined analyses of rRNA and tuf gene sequences. Int J Syst Evol Microbiol 50, 1703-1713.

Page, R. D. (1996). TREEVIEW: an application to display phylogenetic trees on personal computers. Comput Appl Biosci 12, 357-358.

Schneider, B., Seemüller, E., Smart, C. D. \& Kirkpatrick, B. C. (1995). Phylogenetic classification of plant pathogenic mycoplasmalike organisms or phytoplasmas. In Molecular and Diagnostic Procedures in Mycoplasmology, vol. 1, pp. 369-380. Edited by S. Razin \& J. G. Tully. San Diego, CA: Academic Press.

Schneider, B., Torres, E., Martin, M. P., Schröder, M., Behnke, H.-D. \& Seemüller, E. (2005). 'Candidatus Phytoplasma pini', a novel taxon from Pinus silvestris and Pinus halepensis. Int J Syst Evol Microbiol 55, 303-307.

Staniulis, J., Davis, R. E., Jomantiene, R., Kalvelyte, A. \& Dally, E. L. (2000). Single and mixed phytoplasma infections in phyllody- and dwarf-diseased Clover plants in Lithuania. Plant Dis 84, 1061-1066.

Thompson, J. D., Gibson, T. J., Plewniak, F., Jeanmougin, F. \& Higgins, D. G. (1997). The CLUSTAL_X windows interface: flexible 
strategies for multiple sequence alignment aided by quality analysis tools. Nucleic Acids Res 25, 4876-4882.

Urbanaviciene, L., Jomantiene, R. \& Davis, R. E. (2005). First report of barley as host of a phytoplasma belonging to group 16SrI, subgroup B, and ribosomal protein subgroup rpI-B in Lithuania. Plant Dis 89, 339.

Valiunas, D., Jomantiene, R., Davis, R. E., Sindaraviciene, I., Alminaite, A. \& Staniulis, J. (2000). Molecular detection and characterization of phytoplasmas infecting vegetables, legumes, and ornamental plants in Lithuania. Trans Estonian Agric Univ 209, 220-223.
Valiunas, D., Alminaite, A., Staniulis, J., Jomantiene, R. \& Davis, R. E. (2001a). First report of alder yellows phytoplasma in the Eastern Baltic Region. Plant Dis 85, 1120.

Valiunas, D., Alminaite, A., Staniulis, J., Jomantiene, R. \& Davis, R. E. (2001b). First report of aster yellows-related subgroup I-A phytoplasma strains in carrot, phlox, sea-lavender, aconitum, and hyacinth in Lithuania. Plant Dis 85, 804.

Valiunas, D., Alminaite, A., Jomantiene, R., Davis, R. E. \& Maas, J. L. (2004). Possible cause of European blueberry disease is related to North American milkweed yellows phytoplasma. J Plant Pathol 86, 135-140. 